\title{
IEOH MING PEI: UNA IDEA, TRES VARIACIONES
}

IEOH MING PEI: ONE IDEA, THREE VARIATIONS

Alberto Donaire Rodríguez

RESUMEN El texto siguiente es un resumen de mi lección de despedida, el 18 de noviembre de 2006, al jubilarme en la Escuela de Arquitectura de Sevilla. Como no se grabó y nunca llevo escritas mis clases, ésta es una reconstrucción basada en mi guión y en las notas tomadas por algunos asistentes, a los que agradezco su interés.

Por vez primera se celebraba en la Escuela un acto de esta naturaleza, por iniciativa del entonces Director, Jaime Navarro Casas. A él agradezco su presencia y sus palabras, e igualmente a Juan Luis Trillo de Leyva, que hizo una especie de recorrido sentimental de mi paso por la Escuela, que escuché con emoción. En el mismo curso dieron luego su lección de despedida dos profesores que han dejado en nosotros honda huella, Rafael Manzano y José Luis Manzanares. Estos actos son un bello colofón de una carrera académica.

La clase fue una reflexión sobre la arquitectura, al hilo del comentario de tres obras del arquitecto leoh Ming Pei en tres ciudades diferentes: las ampliaciones de la National Gallery de Washington, del Museo del Louvre de París y del Deutsches Historisches Museum de Berlín.

PALABRAS CLAVE leoh Ming Pei, National Gallery, Museo del Louvre, Deutsches Historisches Museum, arquitectura, ciudad.

SUMMARY The following text is a summary of my valedictory lecture, on 18 November 2006, on my retirement from the School of Architecture of Seville. As it was not recorded, and my never having written up my classes, this is a reconstruction based on my outline and the notes taken by some of those present, whom I thank for their interest.

This was the first time an act of this nature was held in the School, on the initiative of the then Director, Jaime Navarro Casas. I thank him for his presence and his words, and also Juan Luis Trillo de Leyva, who made a sort of sentimental journey of my time at the School, to which I listened with emotion. Later, valedictory lectures were given by two teachers who have left a profound imprint on us, Rafael Manzano and José Luis Manzanares. These acts are a beautiful conclusion to an academic career.

The class was a reflection on architecture, with the thread of the commentary on three works of the architect leoh Ming Pei in three different cities: the extensions of the National Gallery of Art in Washington, the Louvre Museum in Paris and the German Historical Museum in Berlin.

KEY WORDS leoh Ming Pei, National Gallery of Art, Louvre Museum, German Historical Museum, architecture, city. 